\title{
The spreading of Antarctic bottom water in the tropical Atlantic
}

\author{
Monika Rhein*, Lothar Stramma, Gerd Krahmann \\ Institut für Meereskunde an der Universität Kiel, Düsternbrooker Weg 20, 24105 Kiel, Germany
}

Received 10 September 1996; received in revised form 4 February 1997; accepted 7 March 1997

\begin{abstract}
Hydrographic and tracer [chlorofluorocarbon (CFC), component F11] data in the tropical Atlantic off Brazil taken in spring 1994 are used to describe the development of the water mass characteristics of Antarctic Bottom Water (AABW) between $10^{\circ} \mathrm{S}$ and $11^{\circ} \mathrm{N}$. To compute the AABW transports, geostrophic computations and directly measured velocity fields are combined. Velocity profiles were measured with the Pegasus profiling system and an ADCP attached to the CTD.

The F11 increase from $10^{\circ} \mathrm{S}$ to $11^{\circ} \mathrm{N}$, mainly in the upper part of the tracer-poor AABW, reveals the mixing of AABW along its path with the overlying North Atlantic Deep Water, which carries a significant F11 signal in the equatorial Atlantic. While propagating north of $5^{\circ} \mathrm{S}$, the AABW shifts to higher salinities at a given temperature.

About one-third of the northward flowing AABW at $10^{\circ} \mathrm{S}(4.8 \mathrm{~Sv})$ and at $5^{\circ} \mathrm{S}(4.7 \mathrm{~Sv})$ west of about $31^{\circ} 30^{\prime} \mathrm{W}$ enters the Guiana Basin, mainly through the southern half of the Equatorial Channel at $35^{\circ} \mathrm{W}(1.5-1.8 \mathrm{~Sv})$. The other part recirculates and some of it flows through the Romanche Fracture Zone into the eastern Atlantic. In the Guiana Basin, west of $40^{\circ} \mathrm{W}$, the sloping topography and the strong, eastward flowing deep western boundary current might prevent the AABW from flowing west: thus it has to turn north at the eastern slope of the Ceara Rise (2.2 Sv). At $44^{\circ} \mathrm{W}$, north of the Ceara Rise, AABW flows west in the interior of the basin in a main core near $7^{\circ} 15^{\prime} \mathrm{N}(1.9 \mathrm{~Sv})$. A net return flow of about $0.5 \mathrm{~Sv}$ was found north of $8^{\circ} 43^{\prime} \mathrm{N}$. A large fraction of the AABW (1.1 Sv) enters the eastern Atlantic through the Vema Fracture Zone, leaving only 0.3 Sv of AABW for the western Atlantic basins. (C) 1998 Elsevier Science Ltd. All rights reserved.
\end{abstract}

\section{Introduction}

The Antarctic Bottom Water (AABW) can be separated into two components (Mantyla and Reid, 1983; Reid, 1989). The upper part of the AABW originates in the

\footnotetext{
${ }^{*}$ Corresponding author.
} 
Circumpolar Current and consists of old deep water masses (Reid, 1989) with negligible chlorofluorocarbon (CFC, component F11) concentrations. For instance, at the Drake Passage, F11 concentrations less than $0.02 \mathrm{pmol} \mathrm{kg}^{-1}$ were observed in 1990 (Roether et al., 1993). AABW components with densities $\sigma_{4}>46.06$ outflow from the Weddell Sea (Weddell Sea Deep Water, WSDW). WSDW exhibits relatively high CFC concentrations owing to its recent contact with the atmosphere (Bullister, 1989). While flowing north, the cold, fresh AABW encounters the southward flowing North Atlantic Deep Water (NADW). NADW is formed in the northern Atlantic Ocean and is warmer and more saline than AABW. Because of its higher density, the AABW is generally found underneath the NADW at the bottom and is characterized by decreasing temperatures and salinities towards the bottom. It is evident that the bottom topography plays an important role in the flow and distribution of AABW in the ocean.

The deepest part of the NADW [OLNADW, Overflow Lower North Atlantic Deep Water, Rhein et al. (1995), henceforth called RSS95] consists mainly of water masses that overflowed the sills between Greenland and Iceland and are characterized by a strong CFC signal even in the tropical Atlantic (Molinari et al., 1992; RSS95). For instance, at $35^{\circ} \mathrm{W}$ off Brazil, the measurements taken during cruise of R.V. Meteor in November 1992 showed an F11 maximum in the OLNADW of about $0.07 \mathrm{pmol} \mathrm{kg}{ }^{-1}$, whereas the AABW flowing into the western North Atlantic carries a small CFC load of about $0.01-0.02 \mathrm{pmol} \mathrm{kg}^{-1}$ (RSS95).

Here we present hydrographic and CFC data below $3500 \mathrm{~m}$ depth on zonal sections along $10^{\circ} \mathrm{S}$ and $5^{\circ} \mathrm{S}$ off Brazil as well as measurements along meridional sections at $35^{\circ} \mathrm{W}, 40^{\circ} \mathrm{W}$ and $44^{\circ} \mathrm{W}$. Additionally, a zonal section was carried out along $4^{\circ} 30^{\prime} \mathrm{N}$ from east of Ceara Rise to $35^{\circ} \mathrm{W}$. Further, three profiles were taken in the Vema Fracture Zone (VFZ) at about $11^{\circ} \mathrm{N}$ (Fig. 1). The data were obtained in February-March 1994 during cruise M27, leg 3, with R.V. Meteor as part of the World Ocean Circulation Experiment (WOCE). To fill the gap between $2^{\circ} \mathrm{N}$ and $3^{\circ} 40^{\prime} \mathrm{N}$ along the $44^{\circ} \mathrm{W}$ section, where no deep CTD profiles were carried out in March 1994, data from earlier cruises in 1990, 1991 and 1992 are used.

In contrast to our previous cruises in the tropical Atlantic (RSS95), the additional sections at $40^{\circ} \mathrm{W}$ and along $4^{\circ} 30^{\prime} \mathrm{N}$, and the extension of the $44^{\circ} \mathrm{W}$ section north to the Mid-Atlantic Ridge (MAR), provide a fairly good coverage of the Guiana Basin. This paper deals with the evaluation of the water mass characteristics and transports of AABW from $10^{\circ} \mathrm{S}$ off Brazil to $11^{\circ} \mathrm{N}$ in the Guiana Basin.

A CTD model Neil Brown Mark III was used. The precision of the temperature and salinity data were $\pm 0.002^{\circ} \mathrm{C}$ and \pm 0.002 . CFC samples were collected using 101 Niskin bottles attached to a rosette. The CFC analyses were done immediately after sampling aboard ship with a gas chromatographic technique similar to that of Bullister and Weiss (1988). The CFC gear was dedicated to measure the low concentrations found in deep water in the tropical Atlantic, and the depths of the water samples were always below $800 \mathrm{~m}$. The precision was on the order of $\pm 0.003 \mathrm{pmol} \mathrm{kg}^{-1}$ for $\mathrm{F} 11$, and the blanks were in the range $002-0.004 \mathrm{pmol} \mathrm{kg}^{-1}$.

Besides geostrophic calculations, direct velocity measurements done with the Pegasus profiling system (Spain et al., 1981) and a lowered ADCP (LADCP; Fischer 


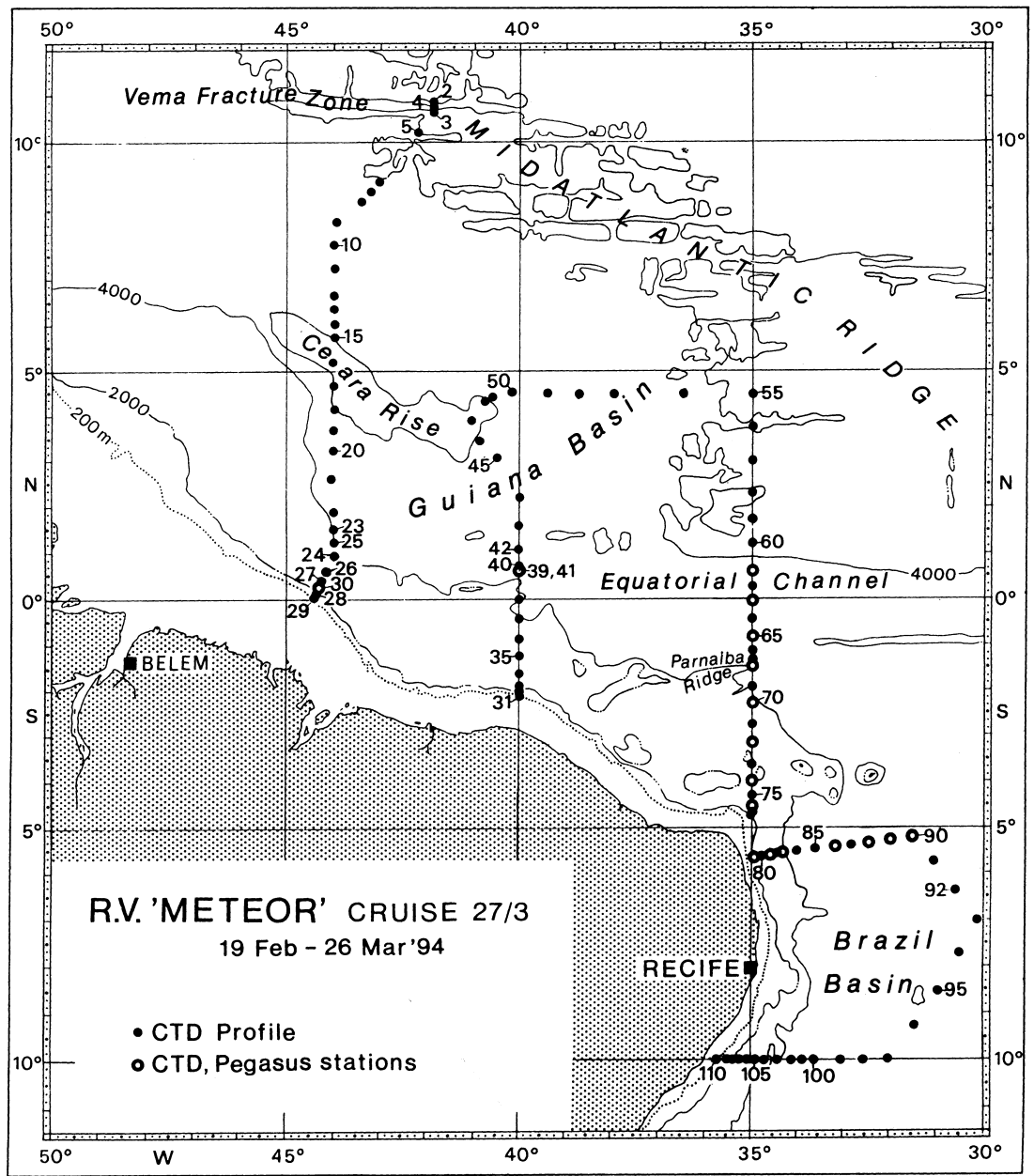

Fig. 1. CTD Stations $(-)$ and combined CTD and Pegasus stations ( $\bigcirc)$ of R.V. Meteor cruise 27, leg 3, 19 February-26 March 1994.

and Visbeck, 1993) are used to evaluate the velocity field and to estimate the transports of $\mathrm{AABW}$ in the tropical Atlantic at $35^{\circ} \mathrm{W}$ and $5^{\circ} \mathrm{S}$. Besides these two sections, one Pegasus profile was carried out at $0^{\circ} 39^{\prime} \mathrm{N}, 40^{\circ} \mathrm{W}$. At that location the water depth was only $4150 \mathrm{~m}$, and thus the profile did not reach the AABW. At the $44^{\circ} \mathrm{W}$ section north of Ceara Rise and at the $40^{\circ} \mathrm{W}$ section no LADCP profiles are available because of technical problems. At $10^{\circ} \mathrm{S}$, a new LADCP instrument was tested, but the data quality was not sufficient to evaluate the velocity profiles in the deep ocean (J. Fischer, 1994, personal communication).

After discussing the boundaries of AABW and the choice of the reference levels for geostrophic calculations, the following section describes the water mass characteristics of AABW following its path from $10^{\circ} \mathrm{S}$ off Brazil to $11^{\circ} \mathrm{N}, 44^{\circ} \mathrm{W}$, in the Guiana 
Basin. Next we present the flow field and transports of AABW in the research area and then discuss a likely circulation pattern of AABW and compare it with previous findings.

\subsection{AABW boundaries and reference levels for geostrophic computations}

In the tropical Atlantic, the definition of the upper limit of the AABW differs depending on the researcher. Roemmich (1983) and Schlitzer (1988) chose the density level $\sigma_{4}=45.92$. However, the associated temperatures at $5^{\circ} \mathrm{S}$ are below $1.5^{\circ} \mathrm{C}$, i.e. they are closely related to the F11 minimum zone, characterizing the upper part of the AABW. Whitehead and Worthington (1982), as well as McCartney (1993) and McCartney and Curry (1993), used the $\Theta=1.9^{\circ} \mathrm{C}$ surface. This temperature is associated with the F11 maximum of the OLNADW and thus is not suitable as a boundary between OLNADW and AABW. This argument holds also for slightly higher temperatures. From RSS95 we adopt the density surface $\sigma_{4}=45.90$ as the boundary between the two water masses. The density surface relates to temperatures of $1.68-1.75^{\circ} \mathrm{C}$ at $10^{\circ}$ and $5^{\circ} \mathrm{S}$, and $1.73-1.81^{\circ} \mathrm{C}$ in the Guiana Basin. In general, it is located slightly deeper than the $\Theta=1.8^{\circ} \mathrm{C}$ surface, which has been used by other workers, e.g. Molinari et al. (1992), Friedrichs and Hall (1993) and Friedrichs et al. (1994).

There is also a variety of reference levels used in the tropical Atlantic. Friedrichs and Hall (1993) studied the circulation on a section perpendicular to the South American coast reaching from $55^{\circ} \mathrm{W}$ off French Guiana to the MAR at $46^{\circ} \mathrm{W}$. To receive a NADW transport comparable with the mean transport obtained by moorings, and to obtain a northward AABW transport, they were forced to choose a reference level between 2000 and 3000 dbar. Their argument against using the boundary between AABW and NADW as a reference level was low transports of NADW. However, it is known that a high variability in the velocity field and transports of the deep western boundary current (DWBC) exists in the tropical Atlantic. For instance, at $44^{\circ} \mathrm{W}$ off Brazil, the NADW transports in a 3 year long time series varied between 7 and $28 \mathrm{~Sv}$ (Fischer and Schott, 1998). On some occasions, even a reversal of the NADW flow was observed (Johns et al., 1993; Schott et al., 1993). This makes the constraint of a large NADW transport in a single hydrographic section questionable. Nevertheless, density surfaces similar to the above-mentioned isobars were applied by Friedrichs et al. (1994) in their geostrophic calculations.

McCartney and Curry (1993) took the $\Theta=1.9^{\circ} \mathrm{C}$ isotherm at $35^{\circ} \mathrm{W}$ as a level of no motion, but because of the water mass characteristics of this temperature layer, the isotherm is located just below the CFC maximum, representing the OLNADW. Moreover, the direct velocity measurements show considerable eastward velocities at that isotherm in the equatorial Atlantic (RSS95), leading to an enhanced AABW transport in using it as a reference level. In our opinion, this isotherm is not suitable as a reference level.

Consistent with the definition of AABW, we selected a reference level of $\sigma_{4}=45.90$. The depth of $\sigma_{4}=45.90$ ranges from 3730 to $3960 \mathrm{~m}$ at $10^{\circ} \mathrm{S}$ and $5^{\circ} \mathrm{S}$, and is located between 3800 and $4300 \mathrm{~m}$ in the Guiana Basin. In general, the presence of a strong 

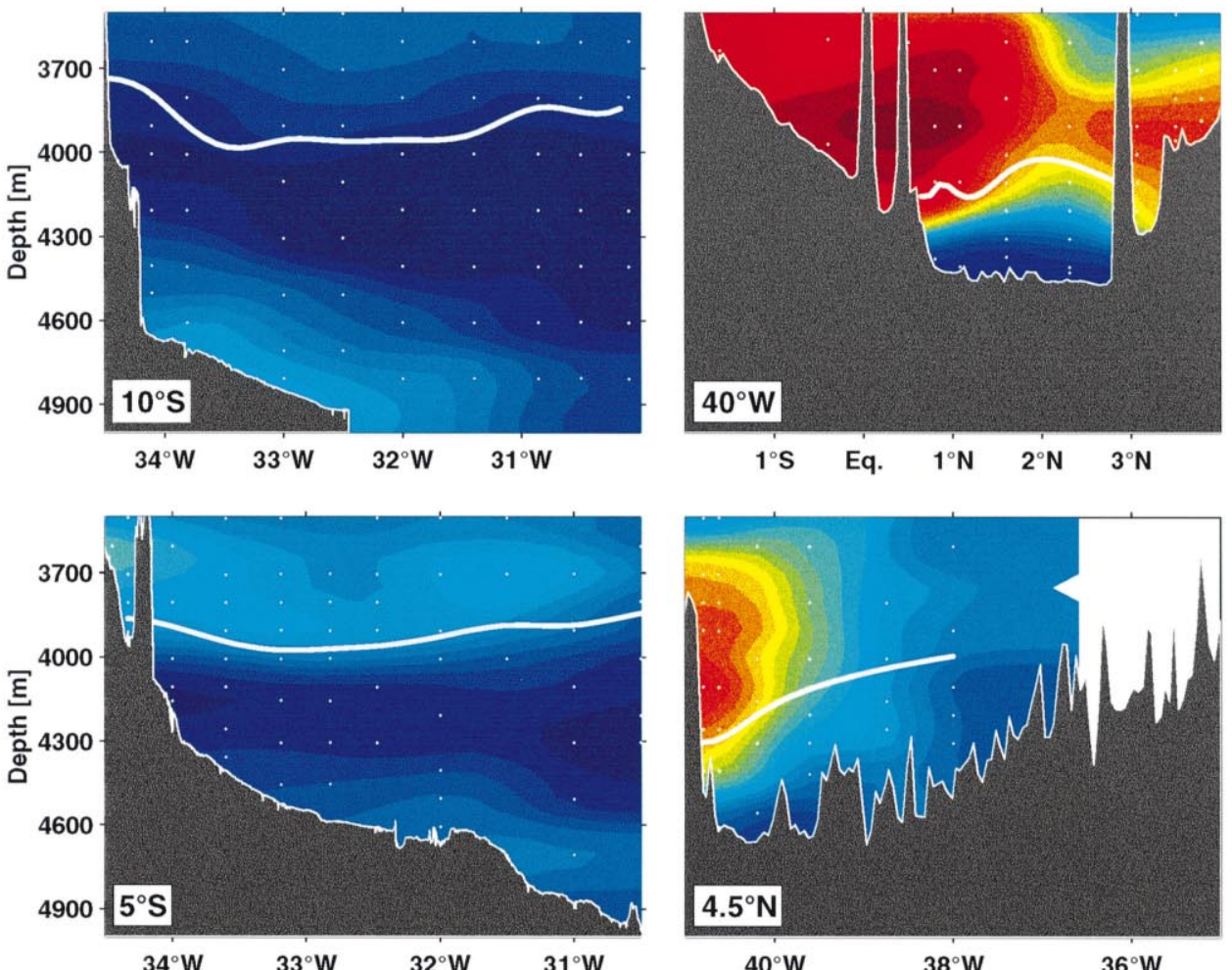

$40^{\circ} \mathrm{W}$

$38^{\circ} \mathrm{W}$

$36^{\circ} \mathrm{W}$
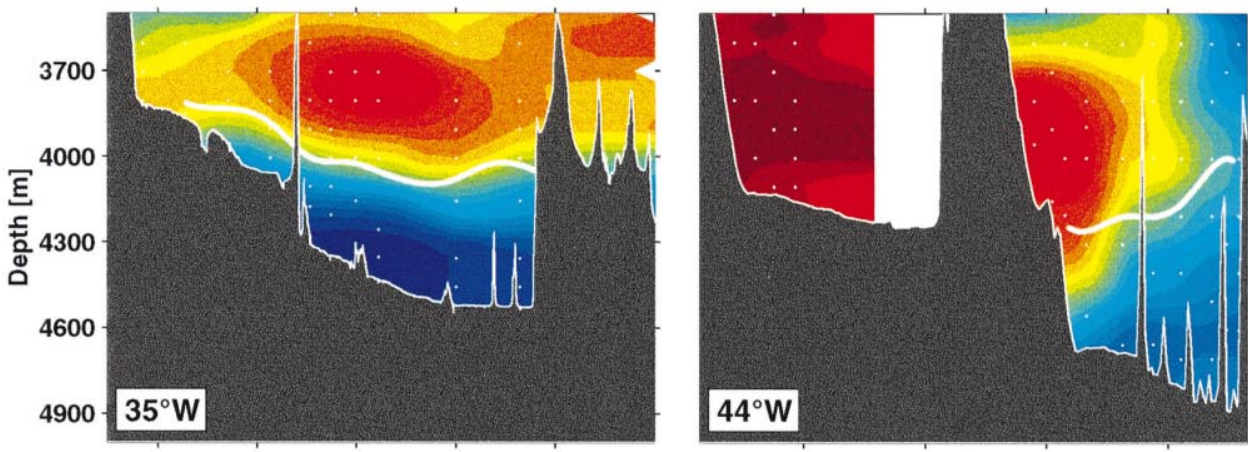

$3^{\circ} \mathrm{S}$

$2^{\circ} \mathrm{S} \quad 1^{\circ} \mathrm{S} \quad$ Eq. $\quad 1^{\circ} \mathrm{N}$

$2^{\circ} \mathrm{N}$

$4^{\circ} \mathrm{N}$

$6^{\circ} \mathrm{N} \quad 8^{\circ} \mathrm{N}$

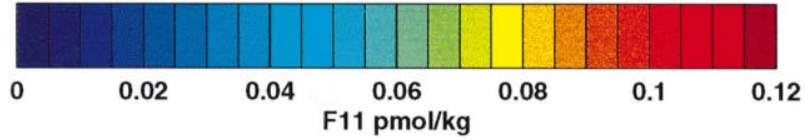

Fig. 2. F11 sections (pmol kg-1) below $3500 \mathrm{~m}$. The $\sigma_{4}=45.90$ isopycnal, the upper boundary of AABW, is shown by the white line. The white dots show the locations of the F11 measurements. 

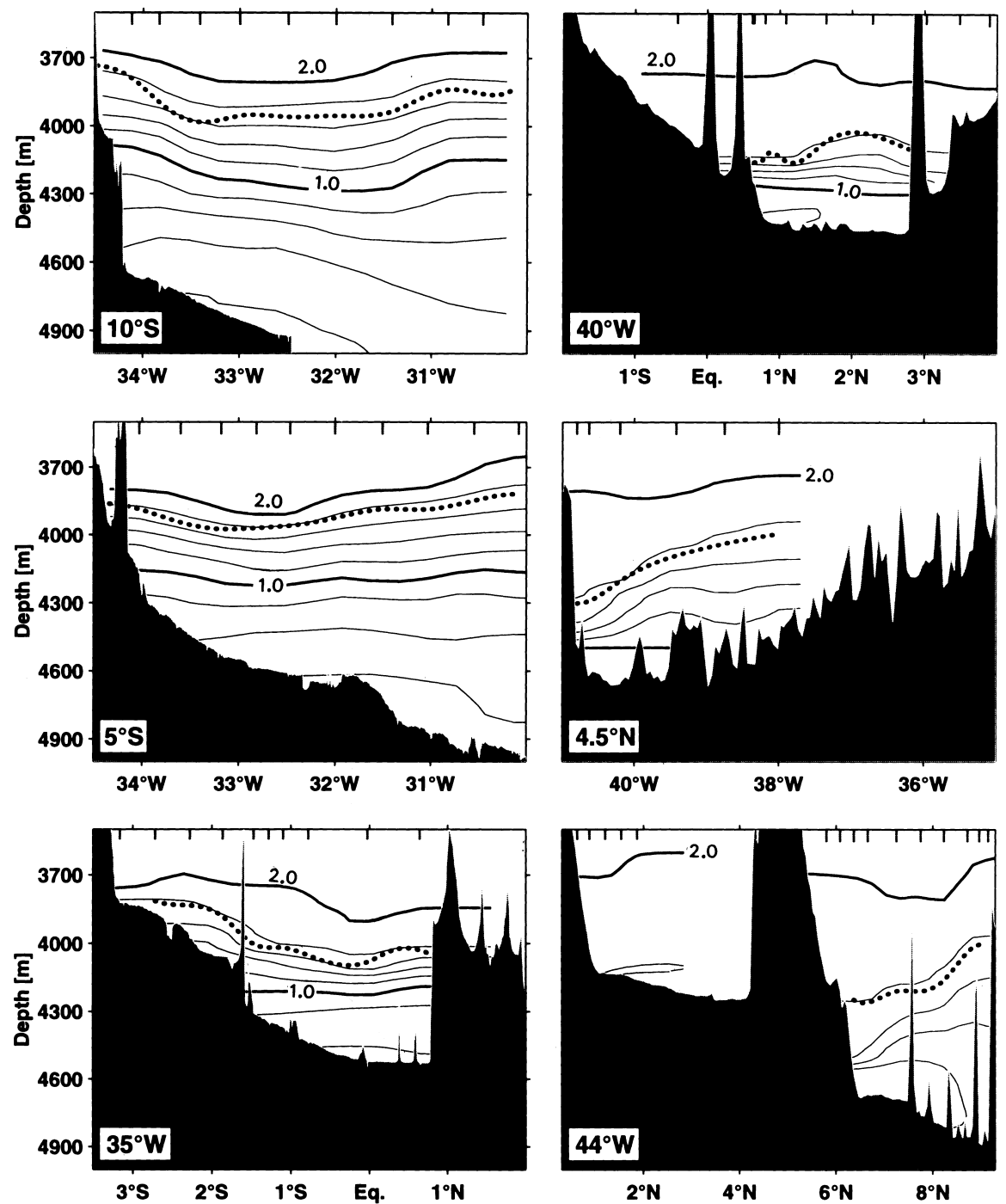

Fig. 3. Potential temperature sections $\left({ }^{\circ} \mathrm{C}\right)$ below $3500 \mathrm{~m}$. The isotherms $2.0^{\circ} \mathrm{C}$ and $1.0^{\circ} \mathrm{C}$ are marked with a thick line; contour interval is $0.2^{\circ} \mathrm{C}$. The $\sigma_{4}=45.90$ isopycnal is shown by a dotted line. The tick marks on top show the location of the CTD profiles. 
reach the bottom, preventing the evaluation of the tracer and velocity field below $5000 \mathrm{~m}$ depth.

\section{2. $5^{\circ} \mathrm{S}$ section}

The $5^{\circ} \mathrm{S}$ section (Figs. $2-4$ ) extends along $5^{\circ} \mathrm{S}$ east to $30^{\circ} 30^{\prime} \mathrm{W}$, then leads southeast to $7^{\circ} \mathrm{S}, 30^{\circ} 05^{\prime} \mathrm{W}$ (Fig. 1). Thus, the meridional section from $10^{\circ} \mathrm{S}$ to $5^{\circ} \mathrm{S}$ is partly OLNADW component causes the depth of this density level to decrease. Velocities are typically small on this isopycnal at $35^{\circ} \mathrm{W}$. Transport estimates based upon the direct velocity measurements differ by less than $20 \%$ from that obtained when the isopycnal $\sigma_{4}=45.90$ is used to reference the geostrophic velocity field. At $5^{\circ} \mathrm{S}$, however, $\sigma_{4}=45.90$ is not always valid as a reference level. There the flow field from about $1200 \mathrm{~m}$ depth to the bottom is almost barotropic (RSS95, see also below). In this case, we took $\sigma_{4}=32.15$ as a reference level, as has been done by Stramma (1991). This density surface is found approximately at 1000-1200 m depth and forms the boundary between the upper Circumpolar Deep Water (uCDW) above this density level and the upper part of the DWBC below. The direct velocity measurements confirm the choice of this reference level at $5^{\circ} \mathrm{S}$.

\section{Spreading of AABW}

\section{1. $10^{\circ} \mathrm{S}$ section}

This section was sampled only to a maximum depth of $5000 \mathrm{~m}$ because of a pressure limitation of the LADCP. The $10^{\circ} \mathrm{S}$ section presented in Fig. 2, Fig. 3a and Fig. 4a follows along $10^{\circ} \mathrm{S}$ from the Brazilian continental margin to $32^{\circ} \mathrm{W}$ and then extends northeastward to $7^{\circ} \mathrm{S}$ (Fig. 1). East of $31^{\circ} 25^{\prime} \mathrm{W}$, the water depth increases from $5110 \mathrm{~m}$ to $5380 \mathrm{~m}$ at $30^{\circ} \mathrm{W}$. Thus our measurements missed the deepest part of the AABW, but water of these deeper layers does not enter the Guiana Basin at $35^{\circ} \mathrm{W}$ : the sill depth of the equatorial channel is located at $4600 \mathrm{~m}$.

The highest densities found at $10^{\circ} \mathrm{S}$ are $\sigma_{4}=46.05$. According to Reid (1989), $\mathrm{AABW}$ with this density is a mixture of water from the Circumpolar Current and from the Weddell Sea. The decreasing vertical temperature and salinity gradients towards the bottom (Fig. 3 and Fig. 4) are remnants of the WSDW, which has in general weaker property changes with depth than the water from the Circumpolar Current (Tsuchiya et al., 1994). The different origin of the water mass components forming the AABW explains the observed F11 profiles in the AABW in the tropical Atlantic: the F11 minimum with concentrations of $0.002-0.007 \mathrm{pmol} \mathrm{kg}^{-1}$ near $\Theta=1.1-1.4^{\circ} \mathrm{C}$ (Fig. 2 and Fig. 3) represents the CFC-free component from the Circumpolar Current, almost unaffected by the CFC-bearing WSDW. Because of the small CFC signals of the other surrounding water masses, mixing with them does not influence the CFC concentrations of the F11 minimum zone.

The F11 increase with density near the bottom shows the influence of the CFC signal of WSDW: the denser layers have less admixture of Circumpolar Water and 

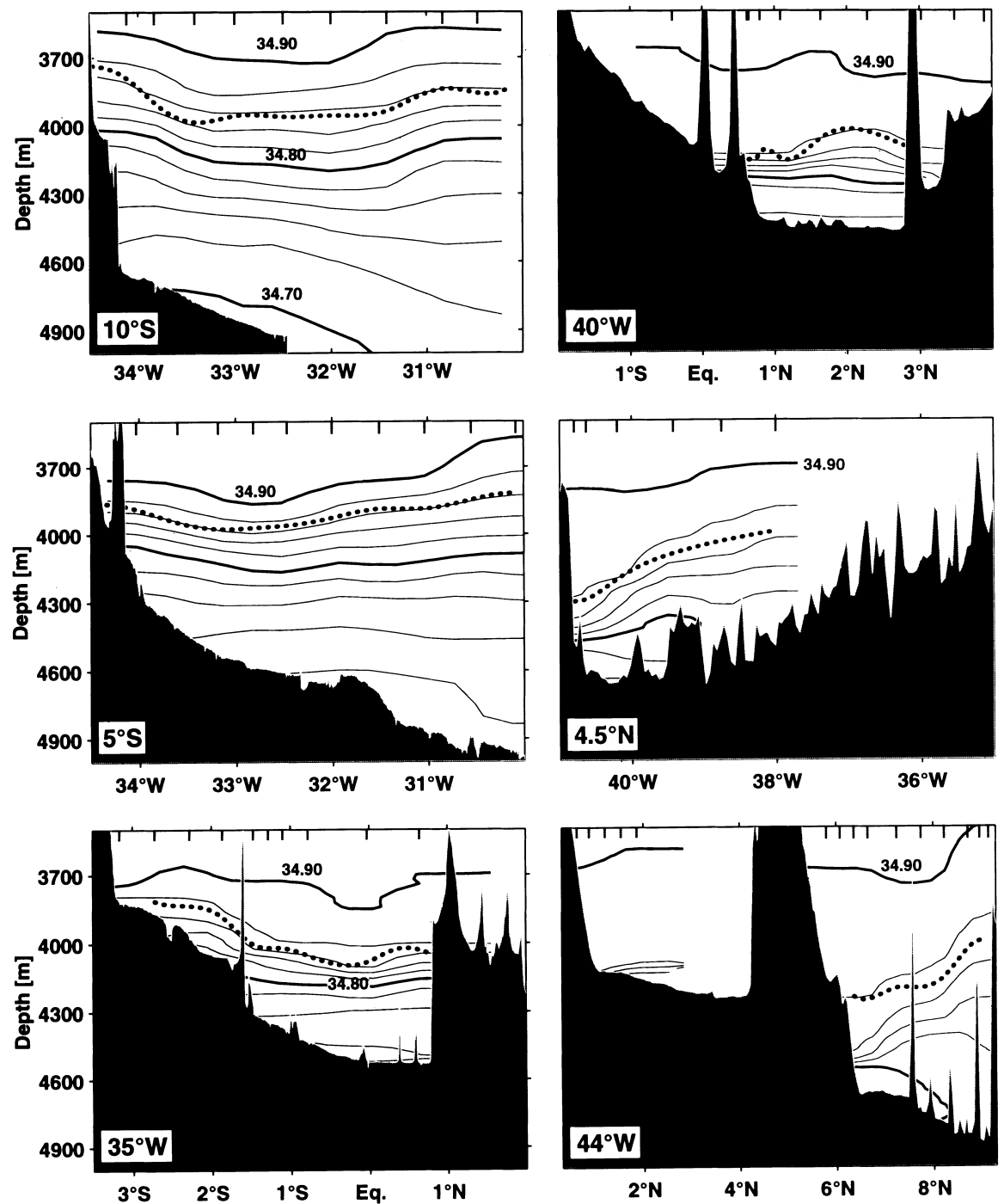

Fig. 4. Salinity sections below $3500 \mathrm{~m}$. The isohalines 34.90, 34.80, 34.70 are marked with a thick line; contour interval is 0.02 . The $\sigma_{4}=45.90$ isopycnal is shown by a dotted line. The tick marks on top show the location of the CTD profiles.

thus higher F11 values. F11 values of $0.040-0.054 \mathrm{pmol} \mathrm{kg}^{-1}$ are found between $32^{\circ} 30^{\prime} \mathrm{W}$ and $34^{\circ} 20^{\prime} \mathrm{W}$ in the $200 \mathrm{~m}$ thick bottom layer $\left(\theta=0.16-0.28^{\circ} \mathrm{C}\right.$; Fig. 2 and Fig. 3), where the lowest salinities were observed (Fig. 4) and where also the highest geostrophic velocities have been calculated. The F11 increase above $\sigma_{4}=45.90$ represents the remnants of the strong F11 signal of OLNADW, the deepest component of the NADW (RSS95). It should be noted that the profiles east of $32^{\circ} 30^{\prime} \mathrm{W}$ do not presented in the $10^{\circ} \mathrm{S}$ section and partly in the $5^{\circ} \mathrm{S}$ section. Because of the sloping 


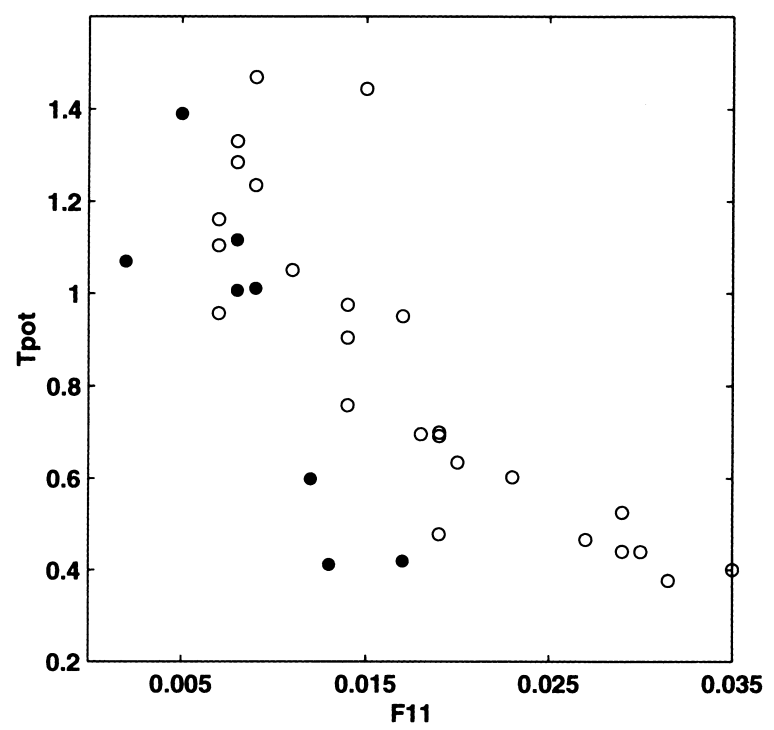

Fig. 5. F11- $\Theta$ correlations for October $1990(\bigcirc)$ and March $1994(\bigcirc)$ at $5^{\circ}$ S.

topography, the maximum densities at $5^{\circ} \mathrm{S}$ are found not to exceed $\sigma_{4}=46.04$ west of $31^{\circ} 30^{\prime} \mathrm{W}$ (deeper levels intersect the bottom, Fig. 3). The highest F11 concentrations observed (0.031-0.035 pmol kg-1) are comparable with the F11 levels found at $10^{\circ} \mathrm{S}$ at the corresponding $\Theta$ level (Fig. 2).

The lower CFC values of the AABW at $5^{\circ} \mathrm{S}$ in March 1994 are caused not by the longer time interval the AABW needs to flow from the formation region to $5^{\circ} \mathrm{S}$ than to $5^{\circ} \mathrm{S}$, but by the lower densities found at $5^{\circ} \mathrm{S}$ than at $10^{\circ} \mathrm{S}$. At a mean velocity of $5 \mathrm{~cm} \mathrm{~s}^{-1}$, typical for the $10^{\circ} \mathrm{S}$ section, the water needs $4-5$ months to travel from $10^{\circ} \mathrm{S}$ to $5^{\circ} \mathrm{S}$. However, if one compares the $\mathrm{F} 11$ signal from October 1990 with the data from March 1994, the F11 increase with time at $5^{\circ} \mathrm{S}$ is evident: for $\Theta$ below $0.8^{\circ} \mathrm{C}$, the F11 concentrations almost doubled (Fig. 5), indicating the arrival of 'younger' AABW in 1994 at $5^{\circ} \mathrm{S}$. The difficulties in using the temporal evolution of a tracer signal to estimate mean spreading velocities and transports were discussed by Pickart et al. (1989), Rhein (1994), and Rhein et al. (1998). Additionally, most of the AABW tracer data of the WOCE South Atlantic cruises are not published yet, and the attempt to estimate the mean spreading velocity and transport of AABW by the CFC distributions has to be postponed to the future.

\section{2. $35^{\circ} \mathrm{W}$ section}

At the equator, the western trough is deformed by major east-west offsets of the MAR and the continental margin of Brazil, forming a nearly zonal abyssal channel about $250 \mathrm{~km}$ wide, in which the AABW is confined (McCartney and Curry, 1993). 


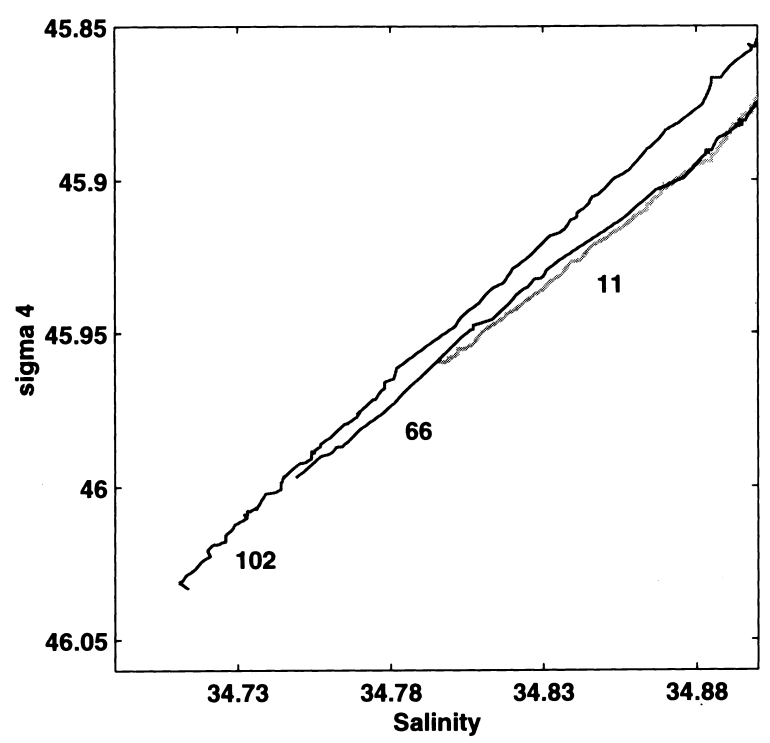

Fig. 6. $\sigma_{4}-S$ correlations for selected profiles representing the sections at $10^{\circ} \mathrm{S}$ (Sta. 102), at $35^{\circ} \mathrm{W}$ (Sta. 66), and at $44^{\circ} \mathrm{W}$ north of Ceara Rise (Sta. 11, gray).

At $35^{\circ} \mathrm{W}$ (Figs. 2-4), the bottom topography forces the AABW to flow westward into the Equatorial Channel between $1^{\circ} 30^{\prime} \mathrm{S}$ and $0^{\circ} 50^{\prime} \mathrm{N}$. AABW is also found south of the Parnaiba Ridge at $1^{\circ} 30^{\prime} \mathrm{S}$, but the topography prevents this water from entering the Guiana Basin (Fig. 1). At $35^{\circ} \mathrm{W}$, within the channel, the topography slopes upward from north to south. The highest densities are found in the deeper part of the channel, i.e. the northern part. The F11 concentrations are higher in the north with decreasing values south of the equator: the lower temperatures $\left(\Theta=0.58^{\circ} \mathrm{C}\right)$ found in the northern part of the channel are below the temperatures $\left(1.1-1.4^{\circ} \mathrm{C}\right)$ of the $\mathrm{F} 11$ minimum. The AABW temperatures near the Parnaiba Ridge are closer to the latter temperature range and thus exhibit lower CFC values. In the northern part of the channel, the vertical extension of this temperature range is only $70 \mathrm{~m}$, in contrast to the conditions at $10^{\circ} \mathrm{S}$, where the layer is $200-300 \mathrm{~m}$ thick. Responsible for the squeezing of this temperature range in the Equatorial Channel is the overlying OLNADW flowing east (Figs 3 and Fig. 4). The F11 distribution at $35^{\circ} \mathrm{W}$ is dominated by the presence of the strong F11 signal of the warmer and more saline OLNADW. By mixing this water with AABW the F11 concentrations for $\Theta>1.0^{\circ} \mathrm{C}$ increase as well as the salinity (Fig. 6).

\section{4. $40^{\circ} \mathrm{W}$ and $4^{\circ} 30^{\prime} \mathrm{W}$}

The maximum density found at $40^{\circ} \mathrm{W}$ (Figs $2-4$ ) was $\sigma_{4}=45.99$ associated with $\theta=0.78^{\circ} \mathrm{C}$. This is colder than the AABW core flowing west between the Parnaiba 


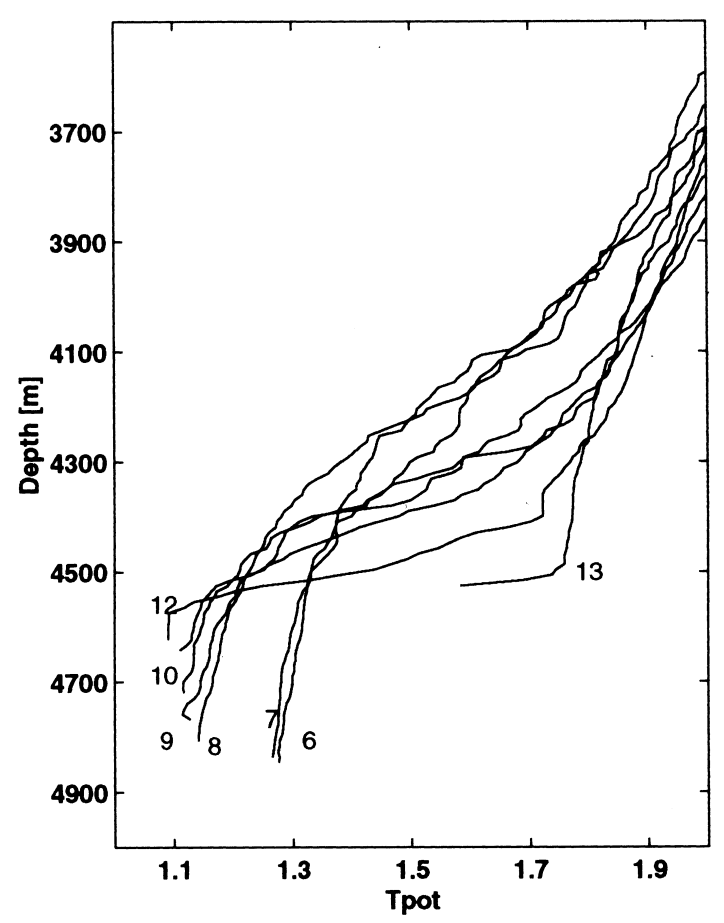

Fig. 7. Potential temperature profiles $6-13$ at $44^{\circ} \mathrm{W}$ from the MAR (Sta. 6) to $6^{\circ} 20^{\prime} \mathrm{N}$ (Sta. 13). Locations of the profiles are shown in Fig. 1. The vertical gradient is most pronounced at Sta. 13. South of this location, AABW is not present.

Ridge and $1^{\circ} \mathrm{S}$ at $35^{\circ} \mathrm{W}$. Thus the lower part of the AABW at $40^{\circ} \mathrm{W}$ presumably originates at $35^{\circ} \mathrm{W}$ from north of $1^{\circ} \mathrm{S}$ in the Equatorial Channel (see below).

The AABW signature at $4^{\circ} 30^{\prime} \mathrm{N}$ is most pronounced between $40^{\circ} 40^{\prime} \mathrm{W}$ and $40^{\circ} 40^{\prime} \mathrm{W}$ east of the Ceara Rise (Figs 2-4), similar to the findings of Whitehead and Worthington (1982). The bottom temperatures are slightly higher $\left(\Theta=0.89^{\circ} \mathrm{C}\right)$ than at the $40^{\circ} \mathrm{W}$ section. The AABW near the Ceara Rise has had sufficient close contact to the high F11 core of the OLNADW to exhibit increased F11 concentrations compared with the more unaffected AABW farther east (Fig. 2).

\section{5. $44^{\circ} \mathrm{W}$ section}

The highest density found at $44^{\circ} \mathrm{W}$ is $\sigma_{4}=45.96$ at $7^{\circ} 15^{\prime} \mathrm{N}$ (4720 $\mathrm{m}$ depth) north of the Ceara Rise, although the largest depths are found further north at $8^{\circ} 58^{\prime} \mathrm{N}$ and $9^{\circ} 09^{\prime} \mathrm{N}$ with $4920 \mathrm{~m}$. At those two locations, the lowest temperatures are $1.27^{\circ} \mathrm{C}$, warmer than at $7^{\circ} 15^{\prime} \mathrm{N}$ with $\Theta=1.10^{\circ} \mathrm{C}$ (Fig. 3). A slight shift to higher salinities occurs compared with the $35^{\circ} \mathrm{W}$ section (Fig. 6), probably because of mixing with the overlying OLNADW. The distribution of $\Theta$ salinity, oxygen and silica in the Guiana Basin shown by Mantyla and Reid (1983) indicated that the core of the AABW is located in the central region of this basin. 
The temperature profiles (CTD profiles 6 and 7, Fig. 1) near the MAR are more homogeneous below $4500 \mathrm{~m}$ depth compared with the profiles farther south (Fig. 7). The homogeneous profiles in temperature and salinity in the vicinity of the MAR could be generated by enhanced vertical mixing, caused by topographically induced mixing near the MAR or associated with a longer residence time, in which the OLNADW and the AABW were in contact with each other. The AABW near the MAR might be a recirculating component.

South of the Ceara Rise, deep CTD profiles were carried out only south of $2^{\circ} \mathrm{N}$. However, measurements done in 1990, 1991 and 1992 showed that south of the Ceara Rise and north of $2^{\circ} \mathrm{N}$, the minimum temperature observed was $1.6^{\circ} \mathrm{C}\left(\sigma_{4}=45.92\right)$ and the boundary between AABW and OLNADW $\left(\sigma_{4}=45.90\right)$ was located $10-80 \mathrm{~m}$ above the bottom between $1^{\circ} 58^{\prime} \mathrm{N}$ and $3^{\circ} 50^{\prime} \mathrm{N}$. South and north of that region, the water did not reach this density level. The temperature associated with $\sigma_{4}=45.90$ was between 1.80 and $1.82^{\circ} \mathrm{C}$ at depths between 4100 and $4120 \mathrm{~m}$. Assuming that the density field in 1994 in the bottom layer is similar to the distribution from 1990 to 1992, the data taken in 1994 did not miss any possible AABW flow south of Ceara Rise.

On the northern flank of the Ceara Rise at $44^{\circ} \mathrm{W}$, east of the Ceara Rise at $4^{\circ} 30^{\prime} \mathrm{N}$, and at the $40^{\circ} \mathrm{W}$ section south of $1^{\circ} \mathrm{N}$ similar conditions (relatively warm and saline water at $\sigma_{4}=45.90$ and corresponding depth deeper than $4100 \mathrm{~m}$ ) have been found. These regions are characterized by a strong OLNADW component, which truncates the boundary between OLNADW and AABW and modifies the water mass characteristics also at deeper levels. This is also visible at the high F11 levels $\left(0.07-0.086 \mathrm{pmol} \mathrm{kg}^{-1}\right)$ below $\sigma_{4}=45.90$, making the water mass characteristic more like that of OLNADW. Because of the truncation of the $\sigma_{4}=45.90$ isopycnal and the sloping topography (Fig. 1), no westward throughflow of AABW could be observed at $44^{\circ} \mathrm{W}$ south of the Ceara Rise, because AABW was not present. Moreover, the direct velocity measurements in previous years $(1990,1991,1992)$ point to a small nearbottom eastward transport of $0.2 \mathrm{~Sv}$ at $44^{\circ} \mathrm{W}$ south of Ceara Rise.

\section{Transports}

\subsection{Direct velocity measurements and geostrophic computations}

The chosen geostrophic reference level of $\sigma_{4}=45.90$ coincides in general with the level of zero or minimal velocity as obtained from the Pegasus and LADCP measurements. Under these circumstances, the calculated transports from both methods agreed rather well despite the different problems associated with these methods. An elaborate discussion on this issue can be found in RSS95. In short, uncertainties regarding the direct measurements are internal wave induced errors (Send, 1994) and insufficient spatial resolution of the flow field. The geostrophic computations are based on the assumption of a reference level with a known velocity. Further drawbacks are the close distance to the equator in some of our sections and the extrapolation of the velocity field on the bottom triangles on a sloping topography. In our 
calculations, the bottom triangles are taken into account by assuming that the velocity at the deepest common depth decreases linearly to zero in approaching the bottom and the transport error is estimated to be on the order of $10 \%$. For the direct velocity measurements, the velocity field in the triangle is calculated using objective analysis. An uncertainty in the barotropic velocity of $\pm 2 \mathrm{~cm} \mathrm{~s}^{-1}$ at the reference level (RSS95) causes a transport error of $0.6 \mathrm{~Sv}$, assuming a vertical extent of $300 \mathrm{~m}$ and a horizontal extent of $100 \mathrm{~km}$. The overall errors (choice of the reference level, bottom triangle errors) on the net $\mathrm{AABW}$ transport numbers across a section are estimated to be on the order of $30 \%$.

Both methods used to obtain a mean transport also suffer from the considerable temporal variability in the velocity field at 30 and 60 day periods that is as high as the average currents in the tropical Atlantic (Johns et al., 1993; Schott et al., 1993). This leads to large uncertainties in interpreting the results of a single cruise.

In the geostrophic velocity field at $5^{\circ} \mathrm{S}$, the 1992 data showed a southward flowing NADW boundary current near the continental shelf and farther east a reverse flow, followed again by a southward flow further offshore. Partly, the AABW joined this flow pattern (RSS95). In 1994, northward flow of AABW occurred near the continental margin off Brazil, whereas in the region where the highest F11 concentrations were observed, the AABW flowed southward. The velocity field obtained with the combined LADCP and Pegasus data, however, shows that the chosen reference level at $\sigma_{4}=45.90$ around $3900 \mathrm{~m}$ depth is not valid for this particular section east of $33^{\circ} 30^{\prime} \mathrm{W}$. Similar features were obtained during November 1992, when the flow field of the NADW lowered the level with minimum velocities.

The combined Pegasus-LADCP velocity field for the upper ocean at $5^{\circ} \mathrm{S}$ showed low velocities at $\sigma_{1}=32.15$ at about $1150 \mathrm{~m}$ depth (J. Fischer, 1994, personal communication). As mentioned above, this is the transition between the upper Circumpolar Deep Water moving north and the upper NADW moving south. Therefore geostrophic computations at $5^{\circ} \mathrm{S}$ were carried out with $\sigma_{1}=32.15$ as the reference level. Additionally, we used the combined Pegasus and LADCP velocity field to compute the AABW transport at $5^{\circ} \mathrm{S}$. In contrast to the presentation of the hydrographic and tracer sections, we present the velocity field in the southern tropical Atlantic along three sections, one zonal section following $10^{\circ} \mathrm{S}$ from the Brazilian coast to $32^{\circ} \mathrm{W}$, one at $5^{\circ} \mathrm{S}$ from the Brazilian coast to $31^{\circ} 30^{\prime} \mathrm{W}$ and a meridional section from $10^{\circ} \mathrm{S}, 32^{\circ} \mathrm{W}$ to $5^{\circ} \mathrm{S}, 31^{\circ} 30^{\prime} \mathrm{W}$ (see Fig. 1).

The flow path of the AABW at $35^{\circ} \mathrm{W}$ is located close to the equator, where geostrophic computations are unreliable. Here, we used the combined Pegasus and LADCP flow field to estimate transports. All transports presented in the following paragraphs are the estimates below the density surface $\sigma_{4}=45.90$, regardless of the choice of the reference level.

\subsection{Transports at the $10^{\circ} \mathrm{S}$ and $5^{\circ} \mathrm{S}$ sections}

At $10^{\circ} \mathrm{S}$, the main northward AABW transport occurs near the Brazilian continental slope at $33^{\circ} 30^{\prime} \mathrm{W}$, and maximum velocities of $12 \mathrm{~cm} \mathrm{~s}^{-1}$ were obtained (Fig. 8). In total, $4.8 \mathrm{~Sv}$ (geostrophic computations) flow northward west of $32^{\circ} \mathrm{W}$, which is more 

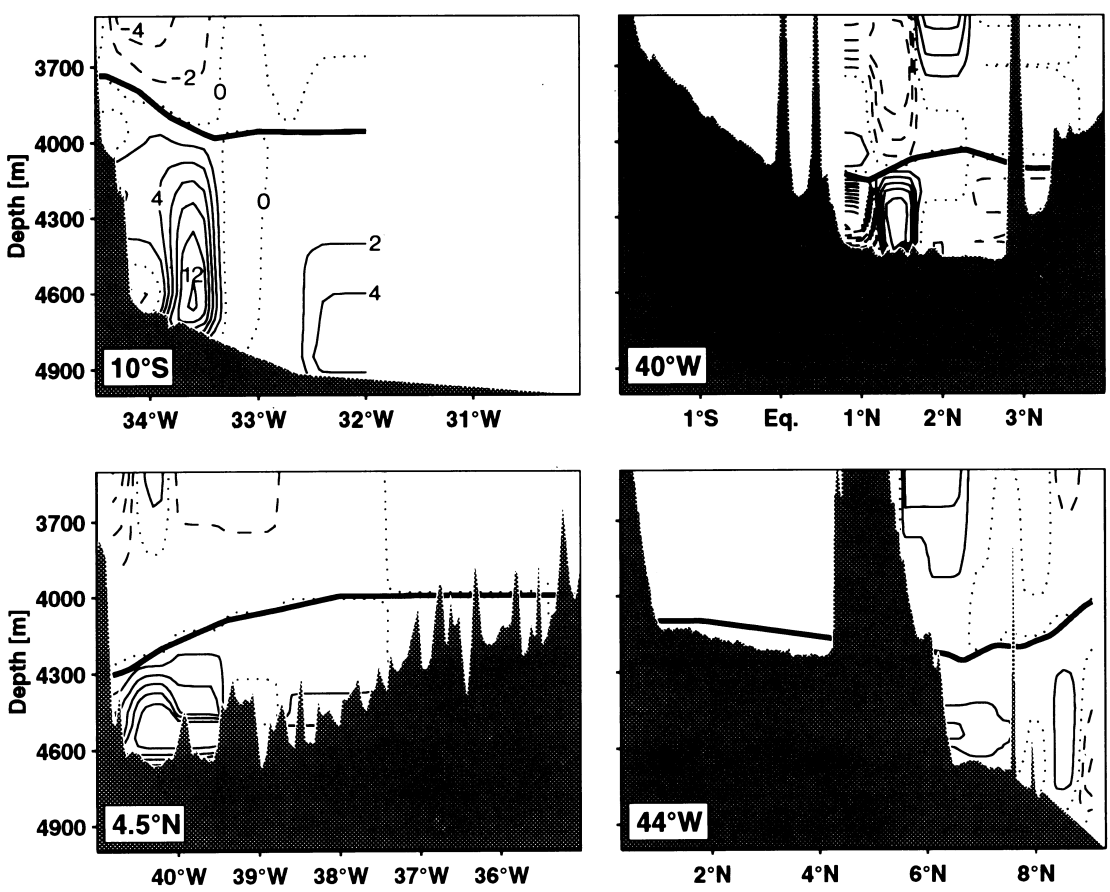

Fig. 8. Geostrophic velocity fields, calculated with a reference level at $\sigma_{4}=45.90$ (thick line), the upper limit of the AABW. Contour interval is $2 \mathrm{~cm} \mathrm{~s}^{-1}$; northward flow or westward flow.
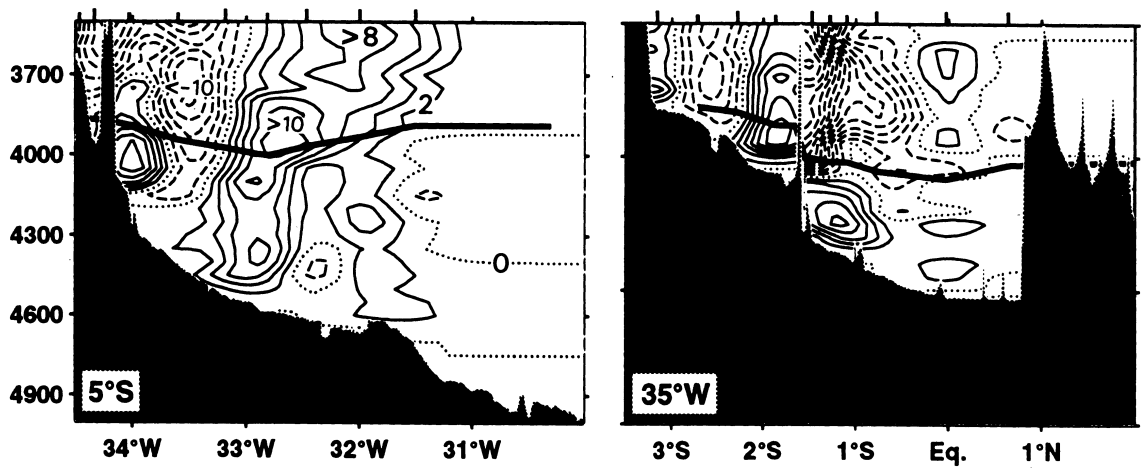

Fig. 9. Velocity fields from direct measurements (combined LADCP and Pegasus); contour interval $2 \mathrm{~cm} \mathrm{~s}^{-1}$, northward flow or westward flow (continuous line); southward or eastward flow (dashed line). The zero velocity line is dotted. Both figures show the isopycnal $\sigma_{4}=45.90$ by a thick line. The tick marks on top show the location of the Pegasus and LADCP profiles.

than was observed in 1992 (0.4 Sv west of $33^{\circ} 30^{\prime} \mathrm{W}$ RSS95). The net northward AABW transport at $5^{\circ} \mathrm{S}$ (Fig. 9) was estimated to be $4.7 \mathrm{~Sv}$ (combined Pegasus and LADCP), also higher than the mean of 1990, 1991 and 1992 (2.4 Sv, RSS95). The geostrophic computations with $\sigma_{1}=32.15$ as a reference level estimate the net northward 
AABW transport to be $4.6 \mathrm{~Sv}$. As mentioned above, the velocity field of the AABW seems to be strongly influenced by the barotropic flow and reversing circulation pattern of the overlying $\mathrm{DWBC}$, making a reliable estimate of the mean AABW transport difficult based on only a few realizations. In contrast to the smaller transports of AABW presented in RSS95, the transports obtained in March 1994 are comparable with geostrophic calculations of transports south of our research area (see below).

The alternation of a meridional flow as observed has been studied by Spall (1994). Using the three-dimensional primitive equations in an idealized basin, Spall found that instabilities of a deep western boundary current change the mean basin bottom flow from cyclonic to anticyclonic.

The inflow of AABW with densities smaller than $\sigma_{4}=46.05$ into the Brazil Basin was estimated to 4.3 Sv (Speer and Zenk, 1993), and DeMadron and Weatherly (1994) reported an inflow of AABW of $7.2 \mathrm{~Sv}$, from which $60 \%(4.3 \mathrm{~Sv})$ were at densities higher than $\sigma_{4}=46.01$. These transports are similar to the $4.75 \mathrm{~Sv}$ northward flow at $5^{\circ} \mathrm{S}$ at densities less than $\sigma_{4}=46.04$.

In our meridional section between $10^{\circ} \mathrm{S}$ and $5^{\circ} \mathrm{S}$ a net inflow into the box of $0.7 \mathrm{~Sv}$ was computed. Within the uncertainties of the transport estimates, the $10-5^{\circ} \mathrm{S}$ box is in balance (inflow $4.8+0.7 \mathrm{~Sv}$, outflow $4.7 \mathrm{~Sv}$, respectively). Besides the accuracy problems discussed above, one has to keep in mind that our measurements along $10^{\circ} \mathrm{S}$ east of $32^{\circ} 30^{\prime} \mathrm{W}$ and on the meridional section from $10^{\circ} \mathrm{S}$ to $7^{\circ} \mathrm{S}$ miss the part of the flow below $5000 \mathrm{~m}$ (bottom depth 5000-5300 m). According to Tsuchiya et al. (1994), the northward flow of dense AABW is confined to the western slope of the Brazil Basin, so that the section used here probably accounts for the major part of the northward transport of AABW.

Of the $4.7 \mathrm{~Sv}$ northward $\mathrm{AABW}$ transport at $5^{\circ} \mathrm{S}$, about one-third flows into the Guiana Basin via the Equatorial Channel at $35^{\circ} \mathrm{W}$. The remaining part flows through the Romanche Fracture Zone ( $\left.\mathrm{RFZ}, 0^{\circ} \mathrm{N}, 20^{\circ} \mathrm{W}\right)$ into the eastern Atlantic, and some of it may also recirculate in the Brazil Basin. Schlitzer et al. (1985) estimated a flow of 3.6 Sv through the RFZ with a $60 \%$ contribution of AABW, i.e. $2.2 \mathrm{~Sv}$, in agreement with the 2.0 Sv inferred by Warren and Speer (1991).

\subsection{Transports of $A A B W$ in the Guiana Basin}

The velocity field in March 1994 at $35^{\circ} \mathrm{W}$ (Fig. 9) reveals similar features to those observed in previous years (RSS95). The eastward flowing OLNADW core is located at the northern side of the Parnaiba Ridge at $1^{\circ} 30^{\prime} \mathrm{S}$. The westward flowing AABW entering the Guiana Basin has its maximum velocities south of the equator at $1^{\circ} 30^{\prime} \mathrm{S}$. In March 1994, about $1.5 \mathrm{~Sv}$ of AABW (derived with the combined Pegasus and LADCP data) entered the Guiana Basin through the equatorial channel at $35^{\circ} \mathrm{W}$. However, the isopycnal $\sigma_{4}=45.90$ used as the water mass boundary was located above the layer with minimum velocities (Fig. 9). If one chooses the zero velocity layer as the upper AABW boundary, a westward transport of $1.8 \mathrm{~Sv}$ is calculated.

These transports are lower than the transport of $4.3 \mathrm{~Sv}$ derived by equatorial geostrophy by McCartney and Curry (1993). Their estimate suffers from the use of the 
isotherm $\Theta=1.9^{\circ} \mathrm{C}$ as a reference level for geostrophic computations. As this isotherm is located in the eastward flowing OLNADW core, the calculated transport numbers are higher. However, our estimates are in agreement with the results of RSS95 (2.6 $\pm 2.0 \mathrm{~Sv})$ and Hall et al. (1994) $(2.1 \mathrm{~Sv})$. The latter transport is a preliminary estimate from current meter moorings in the Equatorial Channel along $36^{\circ} \mathrm{W}$. The moorings confirmed the conclusions of RSS95 that most of the flow occurs in the southern half of the gap. However, the temperature distributions at the $35^{\circ} \mathrm{W}$ and $40^{\circ} \mathrm{W}$ sections show at least a part of the transport apparently occurs north of $1^{\circ} \mathrm{S}$. This is also supported by the current meter moorings of Hall et al. (1994) at the equator.

The geostrophic computations relative to $\sigma_{4}=45.90$ south of $1^{\circ} 06^{\prime} \mathrm{S}$ in March 1994 resulted in a westward transport of $2.3 \mathrm{~Sv}$, also indicating that a large portion of the transport occurs south of $1^{\circ} \mathrm{S}$. The close distance to the equator might induce a large error in the geostrophic computations. Moreover, $0.6 \mathrm{~Sv}$ of the transport results from the bottom triangle assumption and is not based on measured density shears.

In the region south of the Parnaiba Ridge, AABW is also present, with a net westward geostrophic transport of $0.7 \mathrm{~Sv}$. This is probably a time-dependent feature, because the topography prevents a throughflow of this AABW into the Guiana Basin (Fig. 1).

The mean net AABW geostrophic zonal transport at the $40^{\circ} \mathrm{W}$ section south of Ceara Rise is close to zero ( $0.1 \mathrm{~Sv}$ eastward), supporting the conclusion of a negligible AABW transport at the $44^{\circ} \mathrm{W}$ section south of Ceara Rise. However, at $40^{\circ} \mathrm{W}$ two reversing currents in the vicinity of the equator are observed, with $1.3 \mathrm{~Sv}$ flowing west near $1^{\circ} 30^{\prime} \mathrm{N}$ and $1.2 \mathrm{~Sv}$ flowing in the opposite direction near $1^{\circ} \mathrm{N}$ (Fig. 8). The closeness of the equator makes the computations doubtful, but the topography does not contradict such a flow field: the westward flowing AABW meets the upward sloping bottom west of $40^{\circ} \mathrm{W}$ (Fig. 1). The topography prevents the AABW from propagating farther to the west. Instead, AABW has to turn east, probably east of $41^{\circ} 30^{\prime} \mathrm{W}$, forming the observed reverse flow.

At the $4^{\circ} 30^{\prime} \mathrm{N}$ section, the geostrophic flow is directed northward (Fig. 8), with the main transport near the Ceara Rise at $40^{\circ} 20^{\prime} \mathrm{W}$, similar to the findings of Whitehead and Worthington (1982). The total northward transport amounts to $2.2 \mathrm{~Sv}(0.5 \mathrm{~Sv}$ result from the bottom triangle computation), which is, within the uncertainty, similar to the inflow at $35^{\circ} \mathrm{W}$. It also agrees with a zero or near-zero zonal transport at $40^{\circ} \mathrm{W}$ south of the Ceara Rise.

Except north of $8^{\circ} 43^{\prime} \mathrm{N}$, the geostrophic velocity field at $44^{\circ} \mathrm{W}$ north of Ceara Rise shows westward flowing AABW (Fig. 8) with a westward transport of 1.9 Sv. North of $8^{\circ} 43^{\prime} \mathrm{N}$, the geostrophic computations revealed a net eastward transport of $0.5 \mathrm{~Sv}$. The eastward flowing AABW core north of $8^{\circ} 43^{\prime} \mathrm{N}$ could be interpreted by a recirculating component of $\mathrm{AABW}$ coming from the northwest. This would also explain the weaker vertical gradients observed in this region, because the water had more time to mix vertically before reaching the location at $8^{\circ} 43^{\prime} \mathrm{N}$. Another trace of this modified AABW (very low vertical temperature gradients) can be seen in the isolated topographic location at $4^{\circ} \mathrm{N}, 35^{\circ} \mathrm{W}$, where below $3800 \mathrm{~m}$ access exists only from the Guiana Basin. At the $4^{\circ} 30^{\prime} \mathrm{N}$ section, no clear sign of this modified AABW could be detected. 
A flipping of the AABW flow from the western to the eastern side of the Guiana Basin was studied by Speer and McCartney (1992). They concluded that the variable thickness of the AABW layer could be responsible for this flow pattern. The fact that the meridional topographic slope could shift the bottom water flow from east to west was also mentioned by Warren (1981). Pedlosky and Chapman (1993) proposed that the meridional topography slope generates the observed flow distribution. Nof and Olson (1993) demonstrated in their $1 \frac{1}{2}$ layer model that the flipping is caused by geostrophy applied to a deep boundary current, which is separated from the ocean's interior by a front. Onken (1995) studied the spreading of the AABW in a Stommel-Arons type of model, but he could not investigate these effects because of the flat bottom and the uniform layer thickness used in his calculations. Therefore, model investigations seem to support the observations of the changing major flow path of AABW leaving the western side of the basin.

West of our research area, Friedrichs and Hall (1993) studied the deep circulation along a hydrographic section extending from $5^{\circ} \mathrm{N}, 55^{\circ} \mathrm{W}$, off French Guiana to $11^{\circ} \mathrm{N}, 46^{\circ} \mathrm{W}$, at the MAR. They found a recirculation cell with a southeastward return flow of AABW with a transport of $2.5 \pm 0.7 \mathrm{~Sv}$ in the interior of the basin and a northwestward flow near the MAR of $2.6 \pm 0.6 \mathrm{~Sv}$. The reported uncertainties are due to the choice of various reference levels between 2000 and $3000 \mathrm{~m}$. Those workers observed an upward sloping of the deep isotherms representing the AABW towards the MAR in agreement with a northwestern flow. The repeated CTD sections off Barbados by Molinari et al. (1992), however, showed a downward sloping of the isohalines and isotherms in approaching the MAR, similar to our section at $44^{\circ} \mathrm{W}$ and their sections off Brazil, although the spatial resolution of the latter was sparse.

Molinari et al. (1992) only reported the geostrophic transports (relative to $\Theta=4.7^{\circ} \mathrm{C}$ ) for the axis of the DWBC near the South American coast with $2.2 \pm 0.9 \mathrm{~Sv}$ of AABW flowing to the southeast. Their evaluations indicated an AABW transport into the interior of the Demerara Basin (located to the northwest of our research area) between $54^{\circ} \mathrm{W}$ and $50^{\circ} \mathrm{W}$. The flow of AABW further along the western boundary is probably blocked by the sloping topography to the east, so that the AABW could not proceed towards the relatively shallow gap between the continental slope and Ceara Rise (Fig. 1) but has to turn into the interior of the Demerara Basin. The eastward component of the AABW transport at our $44^{\circ} \mathrm{W}$ section north of $8^{\circ} 40^{\prime} \mathrm{N}$ could be an eastward extension of this recirculation.

The importance of the Vema Fracture Zone (VFZ) located near $11^{\circ} \mathrm{N}$ for the inflow of bottom water into the eastern Atlantic has been discussed by, for instance, McCartney et al. (1991). They estimated an eastward transport of AABW of 2.1-2.3 Sv below $2.0^{\circ} \mathrm{C}$ at the eastern exit of the VFZ. Our own measurements in the VFZ near $42^{\circ} \mathrm{W}$ (Fischer et al., 1996) in spring 1994 suggest an eastward transport of $1.1 \mathrm{~Sv}$ below $\sigma_{4}=45.90$, calculated with the reference level at $3640 \mathrm{~m}$ depth, based on direct velocity profiles. For the entire layer below the reference level at $3650 \mathrm{~m}$ depth Fischer et al. (1996) derived a transport of 2.1-2.4 Sv, similar to McCartney et al. (1991), but this transport includes the $1.1 \mathrm{~Sv}$ of $\mathrm{AABW}$ as well as a flow of about $1 \mathrm{~Sv}$ for the OLNADW. 


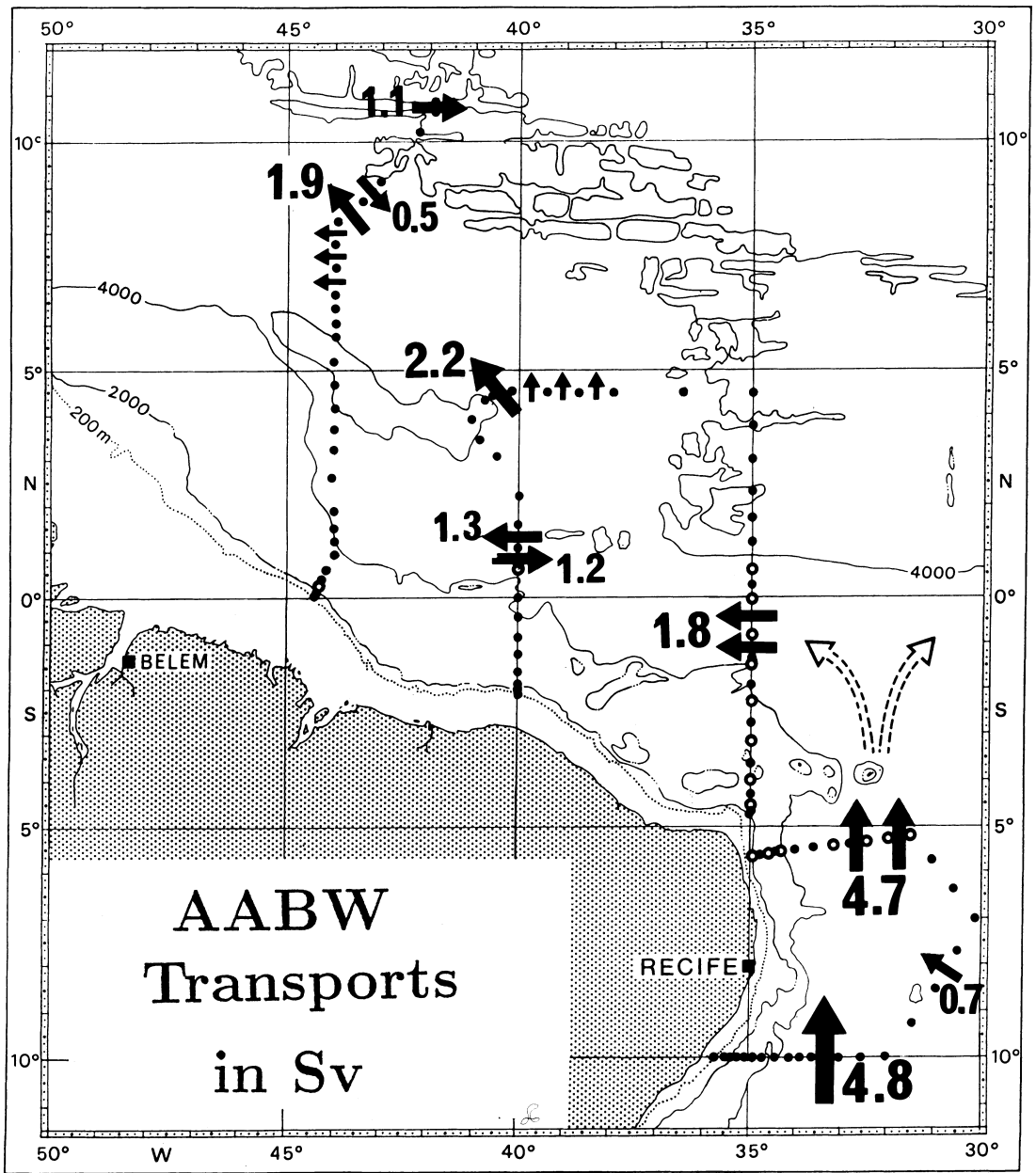

Fig. 10. Circulation and transports of AABW off Brazil, combined from the measurements made in spring 1994. Included is the $4000 \mathrm{~m}$ depth contour, which roughly coincides with the upper boundary of the AABW. The locations of the main transports are shown with thick black arrows, minor transports with thin black arrows. The transport numbers are given in Sv and present the total AABW transports (sum of thick and thin arrows) across the sections. At $40^{\circ} \mathrm{W}$ and at $44^{\circ} \mathrm{W}$, the numbers refer to total eastward and total westward transports.

To summarize, at $44^{\circ} \mathrm{W}$, a net westward transport of $1.4 \mathrm{~Sv}$ below $\sigma_{4}=45.90$ was observed $(1.9 \mathrm{~Sv}-0.5 \mathrm{~Sv})$. About $1.1 \mathrm{~Sv}$ leave the western Atlantic through the VFZ, with a net transport of only $0.3 \mathrm{~Sv}$ proceeding farther to the northwest. Net AABW transports that low were also found by Friedrichs and Hall (1993) and by McCartney (1993) at $52^{\circ} \mathrm{W}$. Klein et al. (1995) estimated an AABW transport at $8^{\circ} \mathrm{N}$ of $0.69 \mathrm{~Sv}$, and north of the $\mathrm{VFZ}$ at $14^{\circ} 30^{\prime} \mathrm{N}$ of $0.31 \mathrm{~Sv}$, which is similar to our conclusions. 


\section{Circulation of $\mathrm{AABW}$ in the equatorial Atlantic}

Despite the high temporal variability in the velocity fields in the tropical Atlantic (Johns et al., 1993; Schott et al., 1993; RSS95) and the various uncertainties in estimating the transports, we combined the results of the previous section and suggest a likely circulation pattern of AABW off Brazil (Fig. 10). The good spatial coverage of the Guiana Basin in 1994 helped to improve the circulation scheme compared with RSS95.

About one-third of the northward flowing AABW at $10^{\circ} \mathrm{S}(4.8 \mathrm{~Sv})$ and $5^{\circ} \mathrm{S}(4.7 \mathrm{~Sv})$ enters the Guiana Basin, mainly through the southern half of the Equatorial Channel at $35^{\circ} \mathrm{W}(1.5-1.8 \mathrm{~Sv})$. The other part flows through the Romanche Fracture Zone into the eastern Atlantic, and part of it may also recirculate in the Brazil Basin. The transports at $10^{\circ} \mathrm{S}$ and at $5^{\circ} \mathrm{S}$ observed in 1994 were higher than the results presented in RSS95, and they are more compatible with estimates farther south. In the Guiana Basin, west of $40^{\circ} \mathrm{W}$, the sloping topography and the truncation of the upper boundary of AABW through the strong, eastward flowing NADW might prevent the AABW from flowing west: thus it has to turn north at the eastern slope of the Ceara Rise (2.2 Sv). The model results of Nof and Olson (1993) and Pedlosky and Chapman (1993) offer additional explanations. At $44^{\circ} \mathrm{W}$, north of Ceara Rise, AABW flows westward in the interior of the basin in a main core near $7^{\circ} 15^{\prime} \mathrm{N}(1.9 \mathrm{~Sv})$. South of $6^{\circ} 22^{\prime} \mathrm{N}$, the $\sigma_{4}=45.90$ intersects the bottom. A net return flow of about $0.5 \mathrm{~Sv}$ was found north of $8^{\circ} 43^{\prime} \mathrm{N}$. This flow was not observed east of $44^{\circ} \mathrm{W}$. However, it could be a remnant of the recirculation found between $52^{\circ} \mathrm{W}$ and $46^{\circ} \mathrm{W}$ by Friedrichs and Hall (1993). As 1.1 Sv leave the western Atlantic through the VFZ, only a net transport of $0.3 \mathrm{~Sv}$ remains for the western basin north of the VFZ.

\section{Acknowledgements}

We thank the captain and crew of the R.V. Meteor cruise M27, leg 3, for their assistance. Dr. J. Fischer kindly provided the LADCP data. T. Elbrächter and O. Plähn performed many of the CFC analyses. We thank F. Schott, J. Fischer, and K. Polzin for helpful discussions and comments. Financial support from the Bundesministerium für Bildung und Wissenschaft (BMBF) is gratefully acknowledged.

\section{References}

Bullister, J.L., 1989. Chlorofluorocarbons as time dependent tracers in the ocean. Oceanography $2,2-17$.

Bullister, J.L., Weiss, R.F., 1988. Determination of $\mathrm{CCl}_{3} \mathrm{~F}$ and $\mathrm{CCl}_{2} \mathrm{~F}_{2}$ in seawater and air. Deep-Sea Research 35, 839-853.

DeMadron, X.D., Weatherly, G., 1994. Circulation, transport and bottom boundary layers of the deep currents in the Brazil Basin. Journal of Marine Research 52, 583-638.

Fischer, J., Schott, F., 1998. Seasonal transport variability of the DWBC in the equatorial Atlantic. Journal of Geophysical Research, in press. 
Fischer, J., Visbeck, M., 1993. Deep velocity profiling with self contained ADCPs. Journal of Atmospheric and Oceanic Technology 10, 764-774.

Fischer, J., Rhein, M., Schott, F., Stramma, L., 1996. Deep water masses and transports in the Vema Fracture Zone. Deep-Sea Research, Part I, 43, 1067-1074.

Friedrichs, M.A.M., Hall, M.M., 1993. Deep circulation in the tropical North Atlantic. Journal of Marine Research 51, 697-736.

Friedrichs, M.A.M., McCartney, M.S., Hall, M.M., 1994. Hemispheric asymmetry of deep water transport modes in the Atlantic. Journal of Geophysical Research 99, 25165-25179.

Hall, M.M., Whitehead, J.A., McCartney, M.S., 1994. Moored measurements of Antarctic Bottom Water at the Equator. International WOCE Newsletter 17, 5-8.

Johns, W.E., Fratantoni, D.M., Zantopp, R., 1993. Deep Western Boundary Current variability off northeastern Brazil. Deep-Sea Research, Part I, 40, 293-310.

Klein, B., Molinari, R.L., Müller, T.J., Siedler, G., 1995. A transatlantic section at $14.5^{\circ}$ N: meridional volume and heat fluxes. Journal of Marine Research 53, 929-957.

Mantyla, A.W., Reid, J.L., 1983. Abyssal characteristics of the World Ocean waters. Deep-Sea Research 30, 805-833.

McCartney, M.S., 1993. Crossing the equator by the Deep Western Boundary Current in the Western Atlantic Ocean. Journal of Physical Oceanography 23, 1953-1974.

McCartney, M.S., Curry, R.A., 1993. Trans-equatorial flow of Antarctic Bottom Water in the western Atlantic Ocean: abyssal geostrophy at the equator. Journal of Physical Oceanography 23, 1264-1276.

McCartney, M.S., Bennett, S.L., Woodgate-Jones, M.E., 1991. Eastward flow through the Midatlantic Ridge at $11^{\circ} \mathrm{N}$ and its influence on the Abyss of the Eastern Basin. Journal of Physical Oceanography 21, 1089-1121.

Molinari, R.L., Fine, R.A., Johns, E., 1992. The deep western boundary current in the western tropical North Atlantic Ocean. Deep-Sea Research 39, 1967-1984.

Nof, D., Olson, D.B., 1993. How do western abyssal currents cross the equator?. Deep-Sea Research, Part I, 10, 235-255.

Onken, R., 1995. The spreading of Lower Circumpolar Water in the Atlantic Ocean. Journal of Physical Oceanography 25, 3051-3063.

Pedlosky, J., Chapman, D.C., 1993. Baroclinic structure of the abyssal circulation and the role of meridional topography. Journal of Physical Oceanography 23, 979-991.

Pickart, R.S., Hogg, N.G., Smethie, W.M., 1989. Determining the strength of the deep western boundary current using the chlorofluoromethane ratio. Journal of Physical Oceanography, 19, 940-951.

Reid, J.L., 1989. On the total geostrophic circulation of the South Atlantic Ocean: flow pattern, tracers and transports. Progress in Oceanography 23, 149-244.

Rhein, M., 1994. The Deep Western Boundary Current: tracers and velocities. Deep-Sea Research, Part I, 41, 263-281.

Rhein, M., Stramma, L., Send, U., 1995. The Atlantic Deep Western Boundary Current: water masses and transports near the equator. Journal of Geophysical Research 100, 2441-2457.

Rhein, M., Plähn, O., Bayer, R., Stramma, L., Arnold, M., 1998. The temporal evolution of the tracer signal in the Deep Western Boundary Current, tropical Atlantic. Journal of Geophysical Research, in press.

Roemmich, D.H., 1983. The balance of geostrophic and Ekman transports in the tropical Atlantic Ocean. Journal of Physical Oceanography 13, 1534-1539.

Roether, W., Schlitzer, R., Putzka, A., Beining, P., Bulsiewicz, K., 1993. A chlorofluoromethane and hydrographic section across Drake Passage: deep water ventilation and meridional property transport. Journal of Geophysical Research 98, 14423-14435. 
Schlitzer, R., 1988. Modeling the nutrient and carbon cycles of the North Atlantic. 1. Circulation, mixing coefficients, and heat fluxes. Journal of Geophysical Research 93, 10699-10723.

Schlitzer, R., Roether, W., Weidmann, U., Kalt, P., Loosli, H.H., 1985. A meridional C-14 and Ar-39 section in Northeast Atlantic Deep Water. Journal of Geophysical Research 90, 6945-6952.

Schott, F., Fischer, J., Reppin, J., Send, U., 1993. On mean and seasonal currents and transports at the western boundary of the equatorial Atlantic. Journal of Geophysical Research 98, $14353-14368$.

Send, U., 1994. The accuracy of current profile measurements-effect of tropical and mid latitude internal waves. Journal of Geophysical Research 99, 16221-16236.

Spain, P.F., Dorson, D.L., Rossby, H.T., 1981. PEGASUS: A simple acoustically tracked velocity profiler. Deep-Sea Research, 28, 1553-1567.

Spall, M.A., 1994. Wave induced abyssal currents. Journal of Marine Research 52, 1051-1080.

Speer, K.G., McCartney, M.S., 1992. Bottom water circulation in the western North Atlantic. Journal of Physical Oceanography 22, 83-92.

Speer, K.G., Zenk, W., 1993. The flow of Antarctic Bottom Water into the Brazil Basin. Journal of Physical Oceanography 23, 2667-2682.

Stramma, L., 1991. Geostrophic transports of the South Equatorial Current in the Atlantic. Journal of Marine Research 49, 281-294.

Tsuchiya, M., Talley, L.D., McCartney, M.S., 1994. Water mass distributions in the western South Atlantic; a section from South Georgia Island $\left(54^{\circ} \mathrm{S}\right)$ northward across the equator. Journal of Marine Research 52, 55-81.

Warren, B.A., 1981. Deep circulation of the world ocean. In Evolution of Physical Oceanography, eds B.A. Warren and C. Wunsch, pp. 6-40. MIT Press, Cambridge, MA.

Warren, B.A., Speer, K.G., 1991. Deep circulation of the eastern South Atlantic Ocean. Deep-Sea Research 38 (Suppl.), S281-S322.

Whitehead, J.A., Worthington, L.V., 1982. The flux and mixing rates of Antarctic Bottom Water within the North Atlantic. Journal of Geophysical Research 87, 7903-7924. 